\title{
Primary telencephalic lymphoma in a horse
}

\section{Linfoma telencefálico primário em um equino}

\author{
Clairton Marcolongo-Pereira ${ }^{1}$; Bruna da Rosa Curcioº ; Douglas Pacheco Oliveira ${ }^{3}$; \\ Ana Carolina Barreto Coelho ${ }^{4}$; Bianca Lemos Santos ${ }^{5}$; Ana Lucia Schild ${ }^{6 *}$
}

\begin{abstract}
A case of T small cell type lymphoma in the brain of a horse is described. A 20 -year-old female Crioulo equine showed neurological signs characterized by ataxia, circling and partial loss of smell and sight. During necropsy, a whitish, firm, unencapsulated mass compressing the structures of the nervous tissue was observed, extending from the olfactory bulb to the internal capsule of the right telencephalon. Microscopic examination showed the proliferation of round cells with a small to moderate amount of eosinophilic cytoplasm. Nuclei were centrally located, irregularly round and occasionally cleaved and hyperchromatic. Immunohistochemistry for CD3 showed a moderate diffuse cytoplasmic staining. This is a rare primary central nervous system lymphoma in horses, with few reports in the veterinary literature. Nevertheless, it should be considered as a differential diagnosis in equines with neurological signs.
\end{abstract}

Key words: Lymphoma, CD3, central nervous system, horse

\section{Resumo}

Descreve-se um caso de linfoma $\mathrm{T}$ do tipo células pequenas no encéfalo de um equino de 20 anos da raça Crioula, que apresentou sinais neurológicos caracterizados por incoordenação motora, andar em círculos e perda parcial do olfato e da visão. Na necropsia havia, desde o bulbo olfatório se estendendo até a cápsula interna do telencéfalo direito, uma massa esbranquiçada e firme, não encapsulada, que comprimia as estruturas do tecido nervoso. Histologicamente havia proliferação de células redondas, com citoplasma escasso a moderado e eosinofílico. Os núcleos eram redondos, localizados centralmente e ocasionalmente endentados e hipercromáticos. Na imuno-histoquímica houve imunomarcação citoplasmática moderada para CD3. Este é um linfoma primário raro do sistema nervoso central de equinos com escassos relatos na literatura veterinária, no entanto, deve ser levado em consideração como diagnóstico diferencial em equinos com sinais neurológicos.

Palavras-chave: Linfoma, CD3, sistema nervoso central, equino

1 Prof. Dr., Faculdade de Veterinária, Centro Educacional Ritter dos Reis, UniRitter, Porto Alegre, RS, Brasil. E-mail: clairton. marcolongo@terra.com.br

2 Prof ${ }^{\mathrm{a}}$ Adjunta, $\mathrm{Dr}^{\mathrm{a}}$, Dept ${ }^{\mathrm{o}}$ de Clínica Veterinária, Faculdade de Veterinária, Universidade Federal de Pelotas, UFPel, Pelotas, RS, Brasil. E-mail: curciobruna@hotmail.com

3 Médico Veterinário, Residente Dept ${ }^{\circ}$ de Clínica Veterinária, UFPel, Pelotas, RS. Brasil. E-mail: douglaspacholi@yahoo.com.br

4 Médica Veterinária, M.e, Discente do Programa de Pós-Graduação em Veterinária, UFPel, RS, Brasil. E-mail: annaccarolina@, hotmail.com

5 Médica Veterinária, Discente do Programa de Pós-Graduação em Veterinária, UFPel, Pelotas, RS, Brasil. E-mail: bi.1.s@hotmail. com

6 Médica Veterinária, Dra ${ }^{\mathrm{a}}$, Pesquisadora do Laboratório Regional de Diagnóstico, UFPel, Pelotas, RS, Brasil. E-mail: alschild@ terra.com.br

* Author for correspondence 


\section{Introduction}

Tumors of the central nervous system (CNS) in horses, with the exception of adenomatous hyperplasia of the pituitary, are uncommon (PARADIS, 1998; ADOLF et al., 2001). Between 1970 and 1997, 25 tumors were found in the CNS of horses in a retrospective study of neoplasms in this species in the United States (PARADIS, 1998). In a survey of equine diseases conducted in southern Rio Grande do Sul between 1978 and 2012, tumors accounted for $19.2 \%$ of the diagnoses, none of which were located in the CNS (MARCOLONGOPEREIRA et al., 2014). Of all of the tumors diagnosed in the CNS of horses, lymphoma is the most common type (PARADIS, 1998).

In horses, lymphomas have been classified into five groups: multicentric, alimentary, mediastinal, cutaneous and solitary (TAINTOR; SCHLEIS, 2011). In most cases, those with CNS involvement are of the multicentric form (ADOLF et al., 2001), with only one report of a primary CNS lymphoma (LESTER et al., 1992). Another report mentions an intradural-extramedullary lymphoma found in a Miniature Shetland pony (FINDING et al., 2014). Lymphoma most frequently involves the spinal column rather than the brain itself, causing clinical signs of paralysis or paresis of the hind limbs and ataxia related to spinal compression (BENTZ et al., 1995; ADOLF et al., 2001; FINDING et al., 2014). The pathogenesis of equine lymphoma is unknown, unlike that reported for bovine and feline lymphomas, which are associated with viral infections (KELLEY; MAHAFFEY, 1998).

The objectives of this report were to describe a primary CNS lymphoma diagnosed in one Crioulo breed horse in southern Brazil and to discuss some aspects of the differential diagnosis with other diseases that cause neurological signs.

\section{Case Report}

One 20-year-old female Crioulo breed horse was presented at the Hospital de Clínicas Veterinária,
Faculdade de Veterinária, Universidade Federal de Pelotas (HCV/UFPel), with a history of neurological clinical signs for a period of three days, in September 2014. This horse, one of a total of three, was in a semi-extensive system with a corn-based diet for three months in winter 2014. The horses had been vaccinated against paralytic rabies. Depression, generalized motor incoordination, head tilt, walking in a circle to the right and head pressing of objects were observed in the neurologic evaluation. When the horse moved to the right side, exacerbated motor incoordination was observed. There was a partial loss both of smell and of sight in his left eye. Changes in the functions of the cranial nerves and spinal cord were not observed. No changes in the white blood cell and erythrocyte counts were identified. Based on the clinical signs, leukoencephalomalacia and cerebral edema of traumatic origin were considered as possible diagnoses. The horse was treated with dexamethasone (1 $\mathrm{mg} / \mathrm{kg}$ iv bid), and phenylbutazone (4.4mg / kg iv bid) for $48 \mathrm{~h}$; due to the worsening of symptoms and the unfavorable prognosis, euthanasia was performed. At necropsy, there were no significant lesions in the abdominal and thoracic cavities. In the right cerebral hemisphere, a whitish, homogeneous, protuberant, unencapsulated, firm mass of $5 \times 3 \times 2.5 \mathrm{~cm}$, extending from the olfactory bulb region to the internal capsule (Figure 1A) and also affecting the meninges of the lateral ventricle wall, was found. The cut surface was whitish with a hemorrhagic area, and the mass was replacing the brain parenchyma, which was compressed (Figure 1B). Fragments of all of the organs of the abdominal and thoracic cavities and the CNS were fixed in $10 \%$ buffered formalin, routinely processed and stained with hematoxylin and eosin. Sections of the CNS were subjected to immunohistochemical examination with antibodies against CD3 (Dako A0452, Dako Cytomation, Carpenter, CA, USA) and CD79a (Dako M7050, Dako Cytomation, Carpentry, CA, USA), both at 1: 100 dilutions, overnight for the identification of Tand B-lymphocytes, respectively. In brief, sections were dewaxed, hydrated, and then subjected to 
microwave pre-treatment for antigen retrieval with citrate buffer. Endogenous peroxidase activity was inhibited with $3 \% \mathrm{H}_{2} \mathrm{O}_{2}$ and non-specific binding was blocked with 5\% nonfat dry milk. All sections were incubated with primary antibodies for 1-2 $\mathrm{h}$ at $37^{\circ} \mathrm{C}$. The fragments were washed and then incubated for $30 \mathrm{~min}$ at room temperature with biotinylated secondary antibodies. Streptavidinperoxidase method (Dako Cytomation, Carpentry,
CA, USA) and 3-amino-9-etilcarbazol (AEC, K3469, Dako Cytomation, Carpentry, CA, USA) were used as the detection system. Later, the slides were washed in distilled water and counterstained with Mayer's haematoxylin, and mounted. Sections of lymph node and tonsil were used as positive controls. For negative controls, instead of the primary antibodies, a phosphate-buffered saline (PBS) solution was used.

Figure 1. An equine with T-cell lymphoma in the brain. A. The horse presented a whitish, homogeneous, protuberant, unencapsulated, firm mass of $5 \times 3 \times 2.5 \mathrm{~cm}$ located in the olfactory bulb and the right frontal cortex region. B. The cutting surface of the tumor replaced the parenchyma and compressed the adjacent brain structures. There was a small area of hemorrhage.
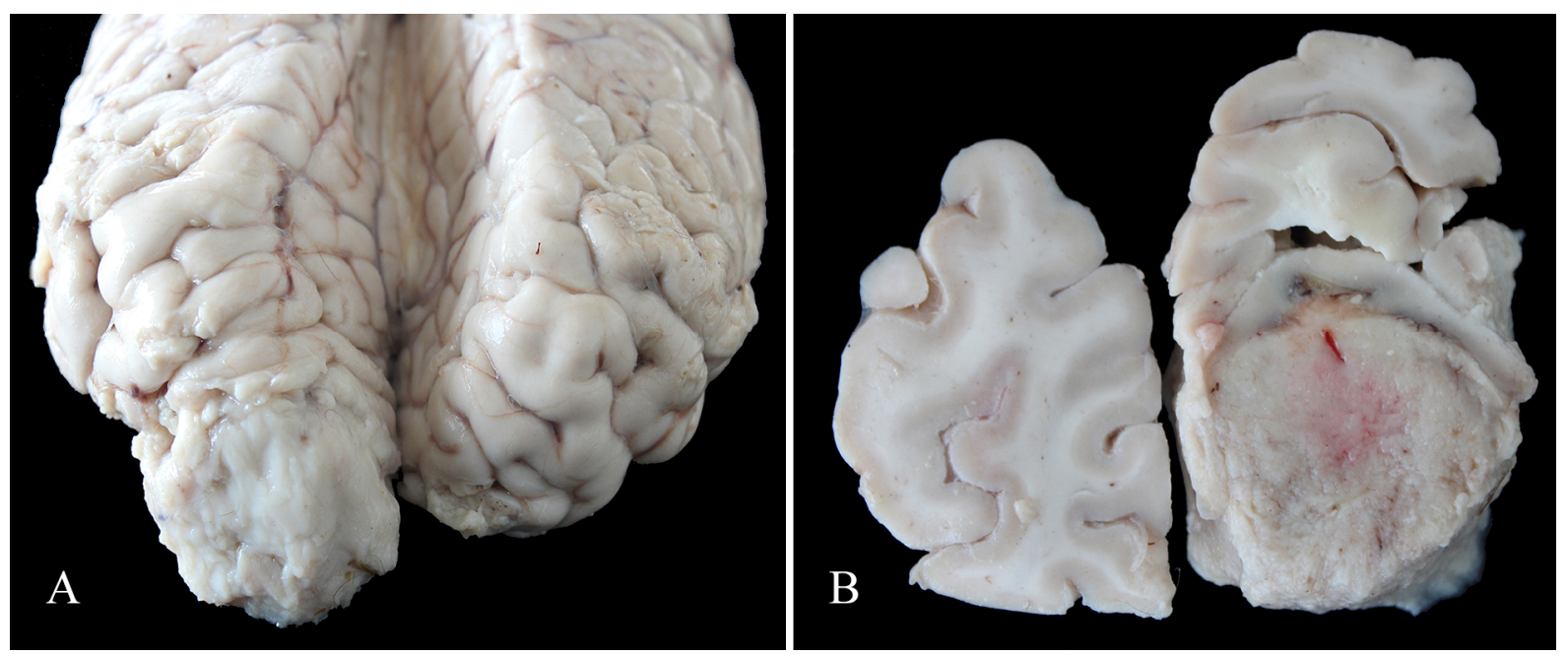

Histologically, proliferation of round cells with sparse to moderate eosinophilic cytoplasm was observed. The nuclei were round, centrally located, and occasionally cleaved and hyperchromatic (Figure 2A). There were three to five mitotic figures per high-power field. Perivascular cuffs of neoplastic cells and hemorrhage were observed in the areas adjacent to the tumor. A focus of neoplastic cells was found infiltrating the neuropil and meninges, and perivascular cuffs were observed in the occipital cortex (Figure 2A). No lesions were found in the other organs. Sections subjected to IHC had moderate cytoplasmic CD3 immunostaining in the neoplastic cells (Figure 2B) and had no cytoplasmic CD79 immunostaining in the neoplastic cells.

The diagnosis of small T-cell lymphoma was based on the macroscopic and histological characteristics and positive immunostaining for CD3. In this case, the main clinical suspicion was leukoencephalomalacia because the horse was fed with corn and its derivatives and the case occurred in an epidemiologically favorable period for this poisoning (RIET-CORREA et al., 2013).

It has been mentioned that cases of lymphoma in the CNS may lead to variable clinical signs of ataxia, lameness, difficulty walking, and paralysis, depending on the location and the growth rate of the neoplasm (ADOLF et al., 2001). In this case, the tumor extended from the olfactory bulb of 
the right hemisphere to the basal ganglia, causing compression in the primary motor area of the cerebral cortex. Lesions in these areas may present clinical signs such as locomotor circling, changes in behavior, and olfactory deficits (KING, 1994), which were also observed in the horse of this report. The visual deficit observed in the horse was probably caused by the presence of tumor cells in the occipital cortex. All of these signs may be observed in cases of leukoencephalomalacia, which is a disease of sudden onset and rapid evolution (RIET-CORREA et al., 2013). The sudden onset of signs and the rapid clinical course were mentioned in another report of CNS lymphoma (LESTER et al., 1992).

Figure 2. An equine with T-cell lymphoma in the brain. A. The frontal cortex showed heavy infiltration of round cells with scant cytoplasm and hyperchromatic round or cleaved nuclei. Perivascular cuffs of neoplastic cells were observed; HE: 20X, inset. Occipital cortex with scattered neoplastic cells; HE, 10X. B. Moderate positive immunostaining for CD3; 40X.

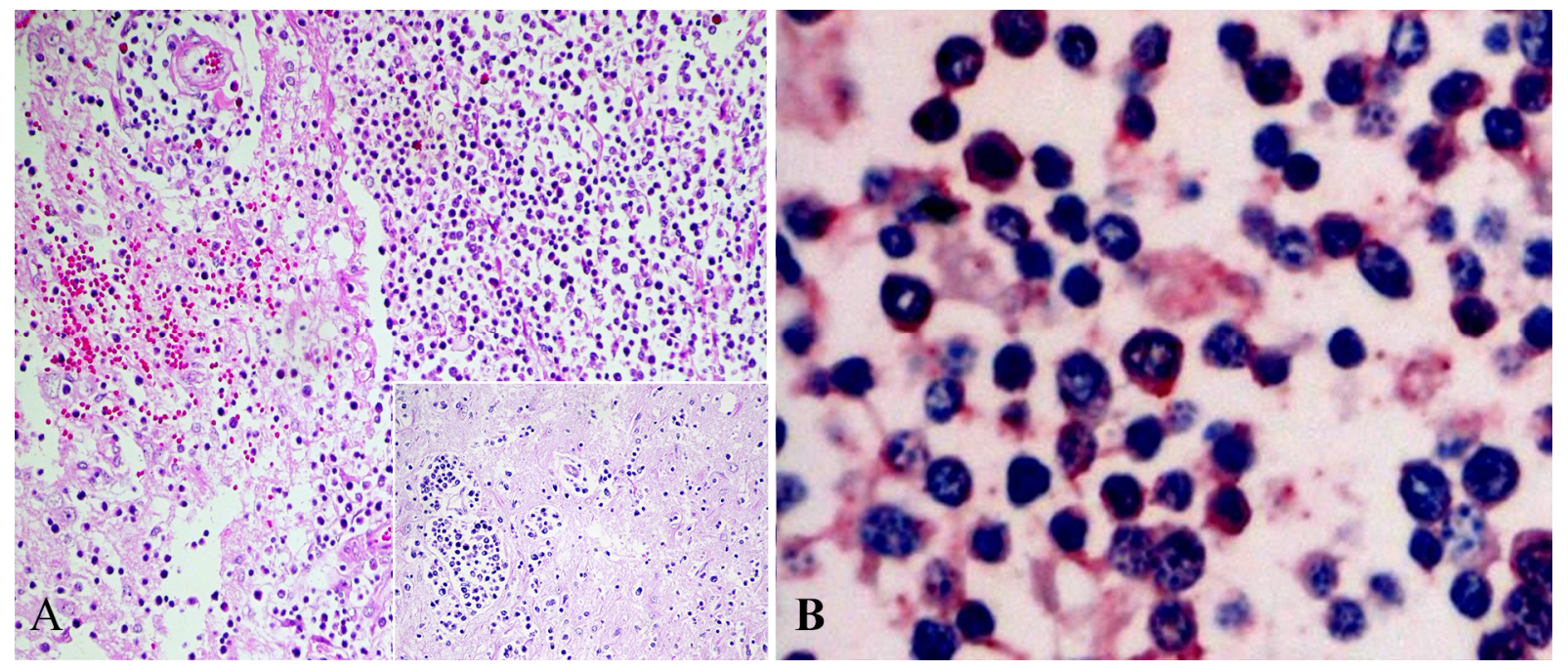

Similarly to leukoencephalomalacia, other diseases such as protozoal myeloencephalitis, trauma, rabies (LAHUNTA; GLASS, 2009), and trypanosomiasis (RODRIGUES et al., 2009) may cause neurological clinical signs similar to those observed in the horse of this report. It is difficult to make a definitive diagnosis of lymphoma in the CNS in vivo. Diagnostic methods with moderate specificity such as cerebrospinal fluid analysis and myelogram may suggest lymphoma in the CNS of horses, but they are not specific enough to confirm the diagnosis (BENTZ et al., 1995; ADOLF et al., 2001).

In other equine CNS lymphomas, the origin of the neoplastic cells (B or $\mathrm{T}$ lineage) was not mentioned. However, in a paper about lymphomas in horses, it was demonstrated that the majority of neoplastic cells were of B cell origin and that T cell lymphomas were less frequent, making up $19.3 \%$ of the cases studied (KELLEY; MAHAFFEY, 1998). Immunophenotyping of neoplastic lymphocytes in horses indicates that the alimentary and multicentric forms are predominantly derived from $\mathrm{T}$ cells, the mediastinal form is usually derived from $\mathrm{T}$ cells, and the cutaneous form is derived from both $\mathrm{T}$ and B cells (BRUIJN et al., 2007). In the horse of the present report, the tumor was composed only of $\mathrm{T}$ cells.

The neoplasm was not observed in any other organ, indicating that this lymphoma was a primary 
tumor of the CNS and was not multicentric. In another report of a primary CNS lymphoma, the tumor was located in the meninges, and perivascular cuffing of the neoplastic cells formed in the cerebral hemispheres, cerebellum, thalamus, and medulla oblongata (LESTER et al., 1992). Despite the rarity of lymphoma presentation in the CNS of horses, lymphoma should be considered in the differential diagnosis of other diseases that affect the CNS.

\section{References}

ADOLF, J. E.; PERKINS, G. A.; AINSWORTH, D. M.; LAHUNTA, A. de. Lymphoma of the central nervous system in horses. Compendium on Continuing Education for the Practicing Veterinarian, Princeton, v. 23, n. 2, p. 194-202, 2001.

BENTZ, B. G.; VANWINKLE, T. J.; BERNARD, W. V. Lymphosarcoma involving the brainstem and spinal cord in a horse. Equine Veterinary Education, Newmarket, v. 7, n. 3, p. 124-126, 1995.

BRUIJN, C. M. de; VEENMAN, J. N.; RUTTEN, V. P. M. G.; TESKE, E.; VAN NIEUWSTADT, R. A.; VAN DEN INGH, T. S. G. A. M. Clinical, histopathological and immunophenotypical findings in five horses with cutaneous malignant lymphoma. Research in Veterinary Science, London, v. 83, n. 1, p. 63-72, 2007.

FINDING, E. J. T.; CLASCA, T.; PINILLA, M. J.; DRIVER, C. J.; JOHNS, I. C.; WELLER, R.; VOLK, H. A. Diagnosis, treatment and outcome of spinal in a pony. Equine Veterinary Education, Newmarket, v. 26, n. 6, p. 303-305, 2014.
KELLEY, L. C.; MAHAFFEY, E. A. Equine malignant lymphomas: morphologic and immunohistochemical classification. Veterinary Pathology, Thousand Oaks, v. 35, n. 4, p. 241-252, 1998.

KING, A. S. Physiological and clinical anatomy of the domestic mammals. Oxford: Oxford University Press, 1994. v. 1, 325 p.

LAHUNTA, A. de; GLASS, E. N. Veterinary neuroanatomy and clinical neurology. $3^{\text {td }} \mathrm{ed}$. St. Louis: Saunders Elsevier, 2009. 540 p.

LESTER, G. D.; MACKAY, R. J.; SMITH-MEYER, B. Primary meningeal lymphoma in a horse. Journal of the American Veterinary Medical Association, Ithaca, v. 201, n. 8, p. 1219-1221, 1992.

MARCOLONGO-PEREIRA, C.; ESTIMA-SILVA, P.; SOARES, M. P.; SALLIS, E. S. V.; GRECCO, F. B.; RAFFI, M. B.; FERNANDES, C. G.; SCHILD, A. L. Doenças de equinos na região Sul do Rio Grande do Sul. Pesquisa Veterinária Brasileira, Rio de Janeiro, v. 34, n. 3, p. 205-210, 2014.

PARADIS, M. R. Tumors of the central nervous system. The Veterinary Clinics of North America. Equine practice, Philadelphia, v. 14, n. 3, p. 543-561, 1998.

RIET-CORREA, F.; RIVERO, R.; ODRIOZOLA, E.; ADRIEN, M. L.; MEDEIROS, R. M. T.; SCHILD, A. L. Mycotoxicosis of ruminants and horses. Journal of Veterinary Diagnostic Investigation, Thousand Oaks, v. 25, n. 6, p. 692-708, 2013.

RODRIGUES, A.; FIGHERA, R. A.; SOUZA, T. M.; SCHILD, A. L.; BARROS, C. S. L. Neuropathology of naturally occurring Trypanosoma evansi infections of horses. Veterinary Pathology, Thousand Oaks, v. 46, n. 2, p. 251-258, 2009.

TAINTOR, J.; SCHLEIS, S. Equine lymphoma. Equine Veterinary Education, Newmarket, v. 23, n. 4, p. 205213, 2011. 
